\title{
Instability of the CGG repeat at the FRAXA locus and variable phenotypic expression in a large fragile $\mathrm{X}$ pedigree
}

\author{
E Pintado, Y De Diego, A Hmadcha, M Carrasco, J Sierra, M Lucas
}

\begin{abstract}
Fragile $X$ syndrome is the major cause of inherited mental retardation. The molecular basis for the expression of the fragile $X$ phenotype is the expansion of an unstable CGG repeat element which inhibits transcription of the FMR1 gene. The fragile $X$ syndrome shows great diversity in its phenotype as well as in its cytogenetic and molecular status. We have studied, in a large fragile $X$ family, the correlation between the molecular data and the phenotypic expression of the syndrome. We report two brothers who carry identical unmethylated premutated alleles but present different clinical phenotypes. We also suggest that reductions in allele size from one generation to another may be, as in other diseases, because of triplet amplifications, more common at the FRAXA locus than previously thought.
\end{abstract}

( $(\mathcal{J}$ Med Genet 1995;32:907-908)

The molecular basis for the expression of the fragile $\mathrm{X}$ phenotype is the expansion of an unstable trinucleotide repeat element which inhibits transcription of the FMR1 gene. ${ }^{12}$ The fragile $\mathrm{X}$ syndrome exhibits great diversity in its phenotype as well as in its cytogenetic and molecular expression. The elucidation of the fragile $\mathrm{X}$ alteration has shown that both the size of the trinucleotide (CGG) repeat segment and the methylation status of the FMR1 gene are likely to explain the severity ${ }^{3-5}$ and the variable phenotypic expression of fragile $\mathrm{X}$ syndrome. $^{6}$ The spectrum of phenotypic expression is particularly poorly defined in non- penetrant or normal transmitting males and in carrier females. ${ }^{7}$ It has been recently shown that the transcription of FMR1 genes with CGG repeat length within the premutation range is normal, ${ }^{8}$ suggesting that subjects with the premutation should not express any of the characteristics of the fragile $\mathrm{X}$ phenotype. We present in this work a large fragile $\mathrm{X}$ gypsy family in which two males carrying the same premutation size have different phenotypes (III·3 and III 4 , fig 1). Medical histories, physical examinations, and psychological tests were obtained for all members of the family. DNA was isolated from peripheral blood samples by the salt precipitation method. ${ }^{9}$ Restriction enzyme polymorphism and methylation were analysed as described previously. ${ }^{10}$ PCR amplification of the CGG repeats at the FRAXA site showed a fragment of $309 \mathrm{bp}$ with an insert of 29 CGG repeats. ${ }^{3}$ PCR products were analysed by both acrylamide and agarose gel electrophoresis. Agarose gels were overloaded in order to see the faint bands. A representative $6 \%$ denaturating acrylamide gel electrophoresis of the CGG repeats is shown in fig 2 . In the third generation there were five brothers, one of them with the full mutation, three with the premutation, and one with the normal allele. III. 3 and III. 4 have an unmethylated premutation with alleles of 101 CGG repeats observed by PCR and Southern blotting (not shown). The physical and psychological examination in most members of the family showed the predicted correlation with the molecular data. However, III 4 showed some features of the fragile $\mathrm{X}$ phenotype, including learning and emotional problems with psychotic behaviour and a physical appearance very common in this syndrome, such as large ears,
Bioquímica Médica Biología Molecular,

Facultad de Medicina

y Hospital

Universitario Virgen

Macarena,

Universidad de

Sevilla, Avda Sánchez

Pizjuán 4, E-41009

Sevilla, Spain

E Pintado

Y De Diego

A Hmadcha

M Lucas

Servicio de

Neurologia, Hospital

Juán Ramón Jiménez,

E-21005 Huelva, Spain

M Carrasco

J Sierra

Correspondence to:

Dr Pintado

Received 28 February 1995 Revised version accepted for publication

26 June 1995

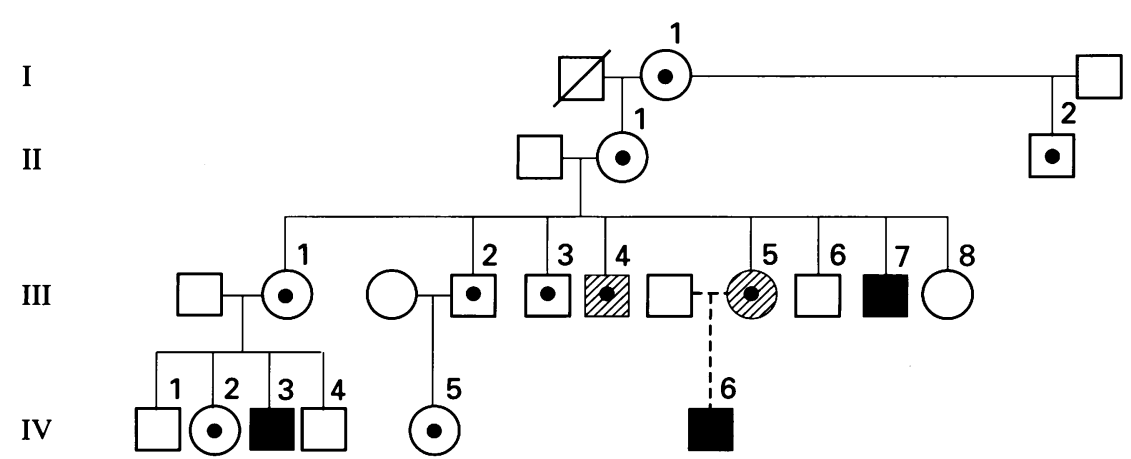

Figure 1 Pedigree of the family. The presence of the affected chromosome in the probands was identified by both linkage analysis and the length of the CGG repeats. Open symbols indicate a normal genotype with a normal phenotype. Filled symbols indicate a full mutation with the complete phenotype of fragile X. Dots indicate carrier status. Hatched symbols with a dot indicate carrier status with mild phenotypic expression. 


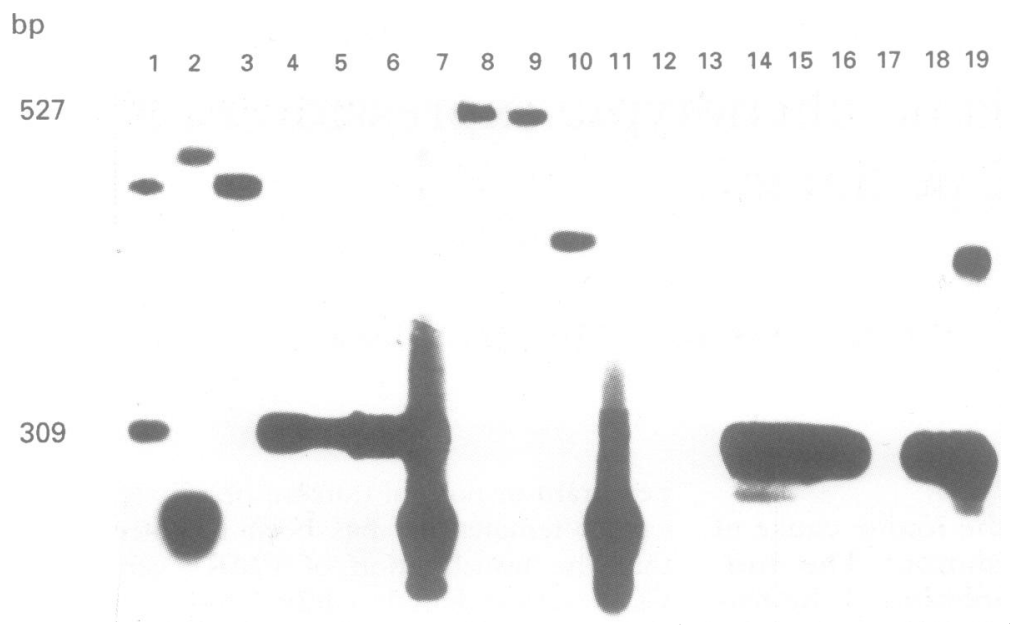

Figure $2 P C R$ study of $C G G$ repeats in the family. The PCR products were separated on a $6 \%$ denaturating acrylamide gel electrophoresis and sized running in parallel ${ }^{32} P$ labelled PBR322 MspI digested fragments. The lane numbers correspond to the following subjects in the pedigree: 1 (I 1 ), 2 (II 1 1), 3 (II $\cdot 2), 4$ (husband of III 1 ), 5 (III 1 ), 6 (III.5), 7 (III.8), 8 (III.3), 9 (III.4), 10 (III.2), 11 (III.6), 12 (III.7), 13 (IV · 3), $14(I V \cdot 2), 15(I V \cdot 1), 16(I V \cdot 4), 17$ (IV.6), 18 (wife of III.2), and 19 (IV.5).

elongated face, and broad forehead. These were present in all the affected males of this family. His overall IQ was in the normal range with a manipulative performance below average. III $\cdot 3$, who had the same size and methylation status of the allele, had a normal IQ and did not show phenotypic expression of the syndrome. For III $\cdot 4$, the term "low expressing", suggested by Loesch $e t a l,{ }^{7}$ could be more accurate than the classic "non-penetrant" or "normal transmitting males". It has been proposed that the broad spectrum of phenotypes in the fragile $\mathrm{X}$ syndrome reflects low level mosaicism for larger, methylated FMR1 alleles or mosaicism in different tissues. ${ }^{8}$ In our fragile $\mathrm{X}$ family, leucocyte DNA showed a mosaic pattern observed by PCR and Southern blotting only in subjects carrying a full mutated allele. A heterogeneous pattern of mutation bands in comparisons between leucocytes and salival epithelial cells has also been shown. ${ }^{11}$ To test for possible mosaicism that could explain the partial fragile X phenotype in III 4 , we have studied, in all the males of this family carrying a premutation, the allele from DNA of three different sources: blood (mesoderm), buccal cells (endoderm), and hair bulb (ectoderm) but no difference in size was found (results not shown). The methylation status was not clearly established owing to an insufficient amount of DNA obtained to do a double digestion. The high variability of expression in the fragile $\mathrm{X}$ syndrome with many different genotype/phenotype relationships ${ }^{1213}$ indicates that further investigations are needed in order to elucidate if the partial expression of the fragile $\mathrm{X}$ syndrome in III 4 is because of the presence of the affected chromosome or is simply a coincidence. It is also worth noting that, in this family, in the passage of the affected chromosome from the second to the third generation the FMR1 allele underwent small amplifications, full amplifications (methylated or unmethylated), and a reduction in the allele size. Thus, retraction, such as observed in III. 2 and IV.5, is a feature that, as in other diseases also resulting from triplet amplification, may be more common at the FRAXA locus than previously thought.

We thank Dr Jean-Louis Mandel, who provided us with the $\mathrm{StB} 12.3$ probe used in this study. We are grateful to $\mathrm{F}$ Bedoya and $M$ Conde for technical assistance. This work was financially supported by Grant No PB92-0676 from the DGICYT.

1 Kremer EJ, Pritchard M, Lynch M, et al. Mapping of DNA instability at the fragile $X$ to a trinucleotide repeat sequence p(CGG)n. Science 1991;252:1711-14

2 Pieretti M, Zhang F, Fu YH, et al. Absence of expression of the FMR-1 gene in fragile X syndrome. Cell 1991;66: $817-22$.

$3 \mathrm{Fu} \mathrm{YH,} \mathrm{Kuhl} \mathrm{DPA,} \mathrm{Pizzuti} \mathrm{A,} \mathrm{et} \mathrm{al.} \mathrm{Variation} \mathrm{of} \mathrm{the} \mathrm{CGG}$ repeat at the fragile $X$ site results in genetic instabililty: resolution of the Sherman paradox. Cell 1991;67:1047-58.

4 Oberle I, Rousseau F, Heitz D, et al. Instability of a 550base pair DNA segment and abnormal methyla

5 Rousseau F, Heitz D, Biancalana V, et al. Direct diagnosis by DNA analysis of the fragile $X$ syndrome of mental retardation. $N$ Engl $\mathcal{F}$ Med 1991;325:1673-81.

6 McConkie-Rosell A, Lachiewich AM, Spiridigliozzi GA, et al. Evidence that methylation of the FMR-1 locus is responsible for variable phenotypic expression of the fragile responsible for variable phenotypic expression of

7 Loesch DZ, Hay DA, Mulley J. Transmitting males and carrier females in fragile X-revisited. Am $\mathcal{F}$ Med Genet carrier females

8 Feng Y, Lakkis L, Devys D, Warren ST. Quantitative comparison of FMR1 gene expression in normal and premutation alleles. Am f Hum Genet 1995;56:106-13.

9 Miller SA, Dykes DD, Polesky HF, et al. A simple salting out procedure for extracting DNA from human nucleated cells. Nucleic Acids Res 1988;16:1215-19.

10 Hallmayer J, Pintado E, Lotspeich L, et al. Molecular analysis and test of linkage between the FMR-1 gene and infantile autism in multiplex families. Am f Hum Genet 1994;55:951-9.

11 Sutherland GR, Brown WT, Hagerman R, et al. Sixth international workshop on the fragile $\mathrm{X}$ and $\mathrm{X}$-linked mental retardation. Conference report. Am $\mathcal{f}$ Med Genet 1994;51:281-93.

12 Rousseau F, Robb LJ, Rouillard P, Derkaloustian VM. No mental retardation in a man with $40 \%$ abnormal methylation at the FMR- 1 locus and transmission of sperm cell mutations as premutations. Hum Mol Genet 1994;3: cell mutatio.

13 Merenstein SA, Shyu V, Sobesky WE, et al. Fragile X syndrome in a normal IQ male with learning and emotional syndrome in a normal IQ male with learning and emotional problems. 